\title{
Cristianismo, paz y violencia Su significado para el diálogo interreligioso
}

\author{
Juan José Tamayo \\ Universidad Carlos III, Madrid
}

La paz es uno de los bienes más preciados y anhelados por la humanidad, pero, al mismo tiempo, uno de los más frágiles y amenazados. Rastreando las huellas de la historia humana, en vano buscaríamos un estado duradero de paz. A lo más, encontraríamos amisticios, breves periodos intermedios entre dos gueras, que no son, precisamente, remansos de paz, sino tiempo dedicado a preparar nuevas guerras. La humanidad -o al menos sus dirigentes, también los religiosos-, parecieran a veces seguir la consigna belicista: "si quieres la paz, prepara la guerra". Una consigna muy alejada del ideal ilustrado de la "paz perpetua", que propusiera Immanuel Kant, en la obra del mismo título, donde podemos leer: "Esta facilidad para hacer la guerra, unida a la inclinación que sienten hacia ella los que tienen la fuerza y que parece congénita a la naturaleza humana, es el más poderoso obstáculo para la paz perpetua". ¡Kant, siempre tan oportuno, tan certero, tan actual!

Entrando, ya directamente en nuestro tema, podemos afirmar que la dialéctica paz y violencia, que recorre la historia de la humanidad, está presente en el cristianismo, desde sus orígenes y lo acompaña a lo largo de su historia bimilenaria, aunque con distintos acentos, según las épocas. La primera constatación que se impone, por su evidencia, es el desequilibrio entre el ideal pacifista del fundador del cristianismo, Jesús de Nazaret, y el carácter no violento del cristianismo primitivo, por una parte, y la implicación de las iglesias cristianas en las distintas formas de violencia, a lo largo de su historia (violencia de género, violencia contra los herejes, cismáticos y heterodoxos, cruzadas, guerras de religiones, etc.), por otra; la falta de sintonía entre la dimensión pacificadora del mensaje del cristianismo y algunas de sus manifestaciones históricas violentas, a través de las cuales logr6 imponerse en muchos lugares por la fuerza de las armas. 
Esta falta de sintonía se aprecia de modo especial en el comportamiento poco tolerante, o directamente beligerante de los cristianos entre sí, como ya observara con gran lucidez Baruc Spinoza, que había sufrido en su propia carne la exclusión de su comunidad judía: "Me ha sorprendido a menudo ver a hombres que profesan la religión cristiana, religión de paz, de amor, de continencia, de buena fe, combatirse los unos a los otros con tal violencia y perseguirse con tan terribles odios, que más parecía que su religión se distinguía por este carácter que por lo que antes señalaba. Indagando la causa de este mal, he encontrado que proviene, sobre todo, de que se colocan las funciones del sacerdocio, las dignidades y los deberes de la Iglesia en la categoría de las ventajas materiales, y en que el pueblo imagina que toda religión consiste en los honores que tributa a sus ministros".

Este artículo se centra, en forma esquemática, en la dialéctica paz-violencia, en la persona, el mensaje y la práctica de Jesús de Nazaret, tal como nos es posible conocer, a través de los métodos histórico-críticos, sociológicos y de antropología cultural, aplicados a los textos del Nuevo Testamento, y en la dialéctica paz-violencia, en algunos momentos más significativos de la historia del cristianismo.

\section{Jesús de Nazaret: ¿pacifista o guerrillero?}

No es la primera vez que se plantea así la pregunta, que puede resultar provocativa e incluso esquemática y reductiva. En esos términos se planteó con especial radicalidad, en la década de los sesenta del siglo XX, en pleno hervor revolucionario en América Latina (movimientos de liberación) y en plena revolución contracultural en Europa (mayo francés), en los inicios de la teología latinoamericana de la liberación y en pleno desarrollo de la teología de revolución.

¿Estaba justificada la apelación tan generalizada de aquellos movimientos revolucionarios, de aquellas manifestaciones contraculturales y de aquellas tendencias teologicas a Jesús de Nazaret como un revolucionario cultural, social y político? ¿Sigue estándolo hoy? Analicemos sus argumentos, antes de hacer una valoración de los mismos.

Hubo toda una corriente de investigadores en tomo a Jesús de Nazaret y a los orígenes del cristianismo que presentaron a Jesús y al cristianismo primitivo en clave revolucionaria. En su libro Origenes y fundamentos del cristianismo, Karl Kautsky ofrecla, a principios del siglo XX, la primera interpretación sistemática del cristianismo primitivo, desde la perspectiva maxista. Tras considerar el cristianismo como uno de los fenómenos más gigantescos de la historia humana y mostrar su admiración por la Iglesia cristiana, tan llena de vigor desde hacla diecinueve siglos, Kautsky presenta a Jesús como un rebelde que muestra un profundo desprecio por las leyes tradicionales e incita a la violencia, y que "fue crucificado como un caudillo fracasado de una insurrección". Así lo muestran, 
cree, las palabras que Mateo pone en boca de Jesús: "Fuego he venido a traer a la tierra, iy qué quiero sino que arda! Tengo que recibir un bautismo: ¡y cómo me angustio hasta que se lleve a cabo!” (Lc 12,49s). “ $¿$ Piensan que he venido a la tierra a dar paz? No, sino disensión. Porque estarán de aquí en adelante cinco en una casa divididos: tres contra dos, dos contra tres. No piensen que he venido a traer paz a la tierra, no he venido a traer paz sino espadas" (Mt 10, 34).

Kautsky considera, además, que la expulsión de los mercaderes y los banqueros del templo hubiera resultado inconcebible sin la ayuda de un grupo de personas incitadas por el propio Jesús. Otro ejemplo que cita a favor de su interpretación es el choque de uno de los discípulos con las fuerzas armadas, que van a detenerlo en el monte de los Olivos: "Y entonces, uno de los que estaban con Jesús, extendiendo la mano, sacó su espada, e hiriendo a un siervo del sumo pontífice le quitó la oreja" (Mt 26,51). El monte de los Olivos era, a su juicio, el lugar indicado para cualquier golpe de Estado contra Jerusalén.

La conclusión que saca Kautsky del análisis precedente es la siguiente: "La presunción de que la ejecución de Jesús fue debida al hecho de ser un rebelde, es, por consiguiente, no sólo la única que puede hacer claras las iniciaciones del evangelio, sino también la única completamente de acuerdo con el carácter de la época y de la localidad"'.

En sintonía con este planteamiento está el del historiador del cristianismo primitivo S. G. F. Brandon, en sus obras, El declive de Jerusalén y la Iglesia cristiana, de 1951, Jesús y los zelotes, de 1967, y El proceso de Jesús, de 1968², donde presenta a Jesús como pro-zelote, crucificado por el procurador Poncio Pilato, por considerarlo un revolucionario, que luchó contra el imperio romano. La prueba principal de dicha actitud sediciosa la encuentra en los sucesos que tuvieron lugar en los últimos días de la vida de Jesús, en Jerusalén. La entrada triunfal en la ciudad santa, cuidadosamente planeada, es, para Brandon, una demostración de la dignidad mesiánica de Jesús, al tiempo que una clara provocación para los dirigentes religiosos y para los romanos. La estrategia de Jesús, al entrar en Jerusalén, montado en un pollino, es deliberadamente mesiánica, si bien reemplaza la semántica zelote corriente, observa F. Belo, quien, siguiendo a

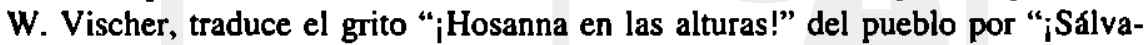
nos! ¡Bendito el que viene en nombre del Señor! ¡Bendito el reino que viene, de nuestro padre David, sálvanos del romano"3. El multitudinario recibimiento de

1. K. Kautsky, Origenes y fuentes del cristianismo, Salamanca, 1974, p. 348.

2. Las ediciones originales son The Fall of Jerusalem and the Christian Church, 1951; Jesús and the Zealots, Manchester, 1967; The Trial of Jesús, Londres, 1968. Una buena sintesis de la teorla de Brandon se encuentra en M. Hengel, Jesús y los revolucionarios de su tiempo, Salamanca, 1974.

3. F. Belo, Lectura materialista del evangelio de Marcos. Relato-Práctica-Ideologí, Estella (Navarra), 1975, p. 271. 
Jesús en Jerusalén es interpretado como mesianico-davídico, de un lado, en la línea de la enseñanza de los escribas, y como independencia nacional, de otro. "En suma - concluye Belo-, es la semántica zelote de la mesianidad la que se instaura alrededor de Jesús y la que dirigirá las secuencias venideras"4.

Una nueva escena de los últimos días en Jerusalén, donde se tiende a ver el carácter revolucionario y sedicioso de Jesús, es el anuncio de la destrucción del templo y la acción contra él, considerada como un ataque violento con la colaboración de sus discípulos y de la multitud, que desembocó en derramamiento de sangre y pillaje. Jesús esperaba que se produjera un enfrentamiento armado, tal como deducen los defensores de esta teoría del discurso de despedida, que dirige a sus discípulos, según el relato del evangelio de Lucas: "El que tenga bolsa, y lo mismo alforja, y el que no tenga, que venda su manto y se compre una espada", como cumplimiento de lo escrito por el profeta Isaías (Is 53, 12).

¿Permiten los relatos evangélicos llegar a esta conclusión? No es fácil responder a esta pregunta con seguridad. A lo más que podemos llegar es a una respuesta aproximada. Así lo hace John Dominic Crossan, quien tras un detallado análisis de los distintos estratos de los textos, cree que el estrato más antiguo implicaría una acción y unas palabras de Jesús paralelas a la acción, ambas relacionados con la destrucción simbólica del templo, que se remontarían al Jesús histórico, como reflejan Marcos 11, 15-16 y Juan 2, 14-16a. Ahora bien, las referencias biblicas y la relación con la destrucción efectiva del templo, con su resurrección o con su segunda venida, son una explicación posterior. Crossan no está muy seguro de que la acción y las palabras de Jesús condujeran derechamente a su detención y ejecucion, pero observa también que, si cuando se produjo fue durante la pascua, es posible que la provocara. En cualquier caso, cree bastante posible que el igualitarismo espiritual y económico que predicaba en Galilea "provocara un estallido de indignación ante el templo en su calidad de sede y símbolo de la mayor desigualdad, de los elementos de patrocinio y opresión existentes tanto a nivel político como a nivel religioso"'.

Abundando en la idea de Jesús como revolucionario, Brandon lee la escena de Getsemaní en clave de resistencia armada, por parte de los discípulos, en legítima defensa frente a la detención de Jesús. La acusación que se le hace a Jesús ante Pilato va en la misma línea: "Hemos encontrado a éste alborotando a nuestro pueblo, prohibiendo pagar tributos al César y diciendo que él es el Mesías, el Rey" (Lc 23, 2). Estas acusaciones, comenta Brandon, tienen un aire de verosimilitud. La condena a muerte en la cruz, el castigo que se imponía a los sediciosos de provincias contra el imperio, sería otra prueba más del carácter revolucionario de la vida de Jesús.

4. Ibid.

5. J. D. Crossan, Jesús: Vida de un campesino judio, Barcelona, 1994, p. 415. 
A favor de esta interpretación cita la versión de las bienaventuranzas de Lucas, que, según este razonamiento, sería la original: "Bienaventurados ustedes los pobres, porque de ustedes es el reino de Dios. Bienaventurados ustedes los que ahora tienen hambre, porque serán saciados. Bienaventurados ustedes los que lloran, porque reirán. Bienaventurados ustedes si los hombres los odian, los expulsan, los insultan y los consideran unos delincuentes a causa del Hijo del hombre... Pero ipobres de ustedes los ricos, porque ya tienen su consuelo! ¡Pobres de ustedes los que ahora están satisfechos, porque después tendrán hambre! ¡Pobres de ustedes los que ahora ríen, porque van a llorar de pena! ¡Pobres de ustedes, cuando todos hablen bien de ustedes, porque de esa misma manera trataron a los falsos profetas en tiempos de sus antepasados!" (Lc 6, 20-24). Lucas no recoge aquí la bienaventuranza dirigida a los mansos y pacíficos, sino sólo a los pobres, a los hambrientos, a los que lloran y a los proscritos, al tiempo que condena a los ricos, a los saciados y a los satisfechos. Es otra señal a favor de la interpretación de Jesús, en clave revolucionaria.

Estos autores vinculan el anuncio de la cercanía del reino de Dios con el movimiento independentista judio, que luchaba contra el poder ocupante, el imperio romano. Más aún, descubren a un militante de la resistencia en el grupo de seguidores de Jesús: Simón, de sobrenombre "zelote".

Ahora bien, ¿cómo interpretan los defensores de esta teoría las actitudes pacifistas de Jesús, que narran los evangelios? Brandon responde que los evangelios, redactados más de cuarenta años después de la muerte de Jesús, falsificaron las tradiciones originarias dándoles un sesgo apologético-pacifista y encubrieron los orígenes y las prácticas revolucionarias de Jesús. Con todo, cree que los evangelios conservan importantes núcleos de la predicación y la praxis sociopolítica revolucionarias de Jesús.

\section{Pacifismo y no violencia activa}

La teoría que acabo de exponer no resulta fácil de ser aceptada, al menos en los términos en que fue propuesta. Sin embargo, tiene elementos muy positivos, que no podemos desconocer y que es necesario recuperar. Jesús de Nazaret no era un judío espiritualista, que se evadiera de la realidad y se refugiara en un mundo ajeno al conflicto. Todo lo contrario. Se muestra sensible a la opresión de su pueblo y comparte las aspiraciones de liberación de sus conciudadanos. Aspiraciones que no pueden separarse de la predicación del reino de Dios, ni de la esperanza de su realización en la historia.

Ahora bien, autores que se mueven dentro de la interpretación marxista de Jesús de Nazaret y del cristianismo primitivo, no dudan en criticar el reduccionismo de las interpretaciones precedentes. En su obra Jesús para ateos, Milan Machovec, filósofo marxista checo, cuestiona la interpretación exclusivamente socioeconómica de Kautsky sobre el cristianismo y considera inadecuada la reducción de todo el 
contenido del cristianismo a los intereses sociales, de la religiosidad a mera forma de expresión, de la concepción del cristianismo como "un movimiento social-revolucionario, una especie de movimiento comunista de la antigüedad" y de Jesús de Nazaret como luchador político de la oposición y revolucionario social". Emst Bloch se muestra muy crftico también con la visión economicista que ofrece el marxismo vulgar sobre el cristianismo revolucionario, y muy especialmente sobre Thomas Münzer y la guerra de los campesinos. "Convendrá, en adelante, examinar a fondo el corazón de los campesinos revoltosos, en lugar de considerar a éstos en un aspecto puramente económico. Si realmente se aspira a comprender lo que entonces sucedió y podía suceder, es ineludible tener en cuenta, además de los motivos económicos, imperativos y clamores de otra índole. Porque las apetencias económicas, siendo, por cierto, las más razonables y constantes, no constituyen la motivación única ni permanentemente vigorosa ni tampoco más genuina del alma humana, sobre todo en tiempos de fuerte agitación religiosa"?

Por lo que se refiere al tema que nos ocupa, cabe afirmar que Jesús de Nazaret no canaliza su lucha por la liberación a través de la violencia armada. Como tampoco recurre a Dios, vinculándolo con la violencia para que instaure el reino de Dios por la fuerza, mientras que sí lo hacían algunos grupos religiosos judíos, en aquella época. El trabajo por la paz, a través de la no-violencia activa, parece ser la actitud que mejor responde a la imagen que de Jesús presentan los evangelios.

El ideal de paz está expresado con toda nitidez en las bienaventuranzas, cuando se declara felices a los "constructores de paz" (Mt 5, 9). El trabajo por la paz es condición necesaria para la felicidad, tanto personal como colectiva y para ser "hijos de Dios".

En los momentos en los que pareciera que el recurso a la violencia era la única forma de respuesta a la violencia institucional del sistema político y religioso y al uso de la violencia por parte del poder que iba a arrestar a Jesús, y cuando uno de los miembros de su grupo hace uso de la espada para defender al Maestro, éste se opone con decisión: "Vuelve tu espada a su lugar; porque todos los que tomaren armas, a espadas perecerán" (Mt 26, 52). Para el, la violencia no es la ley de la historia, como tampoco la solución de los problemas provocados por el poder violento. Si se responde a la violencia con los mismos métodos se entra en una espiral de violencia, que no hay quien la detenga. El objetivo inicial de la violencia puede ser, sin duda, la instauración de la justicia y de la paz, pero el resultado no siempre se corresponde con el objetivo primero y el precio a pagar, sobre todo en vidas humanas, suele ser muy alto. Desencadenada la violencia, ¿quién la detiene?

6. Cfr. M. Machovec, Jesús para ateos, Salamanca, 1974.

7. E. Bloch, Thomas Münzer als Theologe der Revolution, Frankfurt, 1967, p. 61. 
La actitud permanente de Jesús es la denuncia del poder ocupante, que desemboca en opresión del pueblo. Uno de los textos más desmitificadores y críticos del poder en los evangelios, lo encontramos en Marcos, en el cual podemos leer: "Saben que los que son tenidos como jefes de las naciones, las dominan como señores absolutos y sus grandes las oprimen con su poder" (Mc 10, 42). La altemativa al poder que propone Jesús, es el servicio, del cual está ausente toda actitud de dominio (Mc 10, 42-45).

Jesús crea un movimiento de seguidores y de seguidoras, que se sitúa fuera del sistema religioso oficial y del modelo político imperial; un grupo de carismáticos itinerantes, que asumen un estilo de vida radical, caracterizado por la renuncia a la residencia fija, a la familia, a las posesiones y a la propia seguridad. Entre las exigencias de ese movimiento no hay ninguna que haga referencia al uso de la violencia. Los dos valores fundamentales del ethos de Jesús y del movimiento de seguidores y seguidoras son el amor al projimo y la renuncia al status ${ }^{8}$.

El amor al prójimo constituye una radicalización del ethos judío e implica amar al enemigo, al extranjero, como se muestra en la parábola del buen samaritano (Lc 10,25ss), y al pecador (Lc 7, 36ss), como demuestra Jesús al acoger y aceptar a la "gran pecadora", discriminada por sus correligionarios. Quizás la novedad del ethos de Jesús esté en colocar en el centro y en considerar como mandamiento supremo el doble mandato de amor a Dios y al prójimo.

El segundo valor del ethos de Jesús y del movimiento de sus seguidores es la renuncia al status, que implica la relativización y la superación de las diferencias, y la actitud de humildad, que abarca la actitud interior y la conducta exterior, y consiste en la aceptación de su status, por parte de quien pertenece a un estrato social inferior y el aprovechamiento de su status de quien pertenece a un estrato superior para ser solidario con las personas necesitadas.

\section{Amor a los enemigos}

Una de las aportaciones más originales de Jesús es la llamada a amar a los enemigos, que aparece en la fuente Q: "Han oído que se dijo: ojo por ojo y diente por diente. Pero yo les digo: no resistan al mal; antes bien, al que te abofetee en la mejilla derecha ofrécele también la otra... Han oído que se dijo amarás a tu prójimo y odiarás a tu enemigo. Pues yo les digo: amen a sus enemigos y rueguen por los que les persigen" (Mt 5, 38-39.43-44; cfr. Lc 6, $27-$ 28.35). Mateo y Lucas, que se inspiran en ella, ofrecen dos versiones del mismo, coincidentes en lo fundamental, aunque con importantes matices diferenciales. El texto no recoge, es verdad, las mismísimas palabras de Jesús, ya que es

8. Para este punto, cfr. el excelente estudio de Gerd Theissen, La religión de los primeros cristianos, Salamanca, 2002, especialmente pp. 87-105. 
redaccional. Pero los especialistas convienen en que expresan la verdadera intención, y también la actitud y la práctica de Jesús.

El texto muestra una imagen acogedora y bondadosa de Dios. Es en ella donde se encuentra la motivación religiosa del amor a los enemigos: "Amen a sus enemigos y rueguen por los que les persiguen, para que así sean hijos de su Padre que está en los cielos. Porque él hace salir su sol sobre malos y buenos, y llover sobre justos e injustos" (Mt 5, 45); "Amen a sus enemigos... entonces la recompensa de ustedes será grande y serán hijos del Altísimo, que es bueno con los ingratos y los pecadores" (Lc 6, 35) .

Conviene observar que se habla de los enemigos en plural. Por tanto, no se refiere sólo al enemigo personal, sino al enemigo colectivo, que tiene capacidad y poder para perseguir. En consecuencia, el imperativo ético se dirige también a un sujeto colectivo: “iAmen a sus enemigos!”. Por mor del rigor histórico, hay que llamar la atención sobre un dato que no suele ser conocido, y si lo es, no se tiene en cuenta, cuando se analiza el texto neotestamentario: el mandato de odiar a los enemigos no se encuentra en la Biblia hebrea. G. Theissen hace ver a este respecto que el precepto del amor a los enemigos y la no violencia como estilo de vida y como método de acción tuvieron su Sitz im Leben en la Palestina de la época de Jesús, y no fueron sólo propuestas reformadoras de un judío utśpico, que viviera fuera de la realidad. Cita dos ejemplos muy clarificadores al respecto: las manifestaciones de protesta no violenta de algunos judíos contra el intento del procurador Poncio Pilato de introducir en el templo de Jerusalén emblemas imperiales y las dirigidas contra la pretensión de Cayo Calígula de dedicar el templo a otro soberano. De ambos intentos da cuenta el historiador judío Flavio Josefo.

El mandamiento del amor al enemigo es válido universalmente. Su universalidad radica en que ese mandamiento coincide, en buena medida, con el esfuerzo de los pueblos por superar la venganza y el odio, expresado en las diferentes tradiciones sapienciales, legales, religiosas y filosoficas, y en las distintas legislaciones. Sirvan algunos ejemplos. La sabiduría babilónica hace esta exhortación: "No trates mal a tu opositor. Págale con el bien a aquel que te hace el mal". La sabiduría egipcia exhorta de manera similar: "no des lugar a la venganza, para que

9. Son numerosos los estudios sobre el imperativo del amor a los enemigos. Cito estos cinco que me parecen de especial lucidez teologica y exegética: G. Barbaglio, ¿Dios sádico? Lectura de las Escrituras hebreas y cristianas, Estella (Navarra), 1992, pp. 153-161; idem., "L'amore dei nemici", Bozze 4 (1985) 23-33; F. Houtart, "El amor a los enemigos y la lucha de clases", Concilium 303 (noviembre 2003) 139-148; L. Schottroff, "Gewaltverzicht und Friedensliebe in der urchristlichen Jesus (Mt 5, 38 45; Lk , 27-36)", en Conzelmann (ed.), Jesús Christus in Historie und Theologie, Tubinga, 1977, pp. 191-22; G. Theissen, "La renuncia a la violencia y el amor al enemigo (Mt 5, 38-48/Lc 6, 27-38) y su trasfondo social", en G. Theissen, Estudios de sociologla del cristianismo primitivo, Salamanca, 1985, pp. 103-148. 
Dios no tome venganza de tu injusticia". En la sabiduría china leemos: "venga el rencor con la virtud". Epicteto defiende el amor al adversario como exigencia ética positiva ${ }^{10}$.

En todas las religiones hay un imperativo categórico conocido como "regla de oro" del comportamiento humano, que puede ser llevado a la práctica, en todas las situaciones, en que puedan verse inmersos sus seguidores. La encontramos en Confucio: "Lo que no deseas para ti, no lo hagas a los demás seres humanos". En el judaísmo, el Rabbi Hillel la formula así: "No hagas a los otros lo que no quieres que te hagan a ti". Los evangelistas Mateo y Marcos la ponen en boca de Jesús, en estos términos: "Todo cuanto quieran que les hagan los hombres, háganselo también ustedes" (Mt 7, 12; Lc 6, 31a).

El amor a los enemigos ha sido objeto de severas críticas, por parte de relevantes pensadores de nuestro tiempo. Voy a referirme a dos que me parecen emblemáticas, tanto por los autores que las defienden, como por el contenido tan inhumano que encierran. Friedrich Nietzsche escribe en La genealogia de la moral: "Cuando los oprimidos, los pisoteados, los esclavizados, bajo el imperio de la astucia vindicativa de la impotencia, dicen 'seamos lo contrario de los malos, es decir, buenos. Bueno es el que no ejerce violencia sobre nadie, el que no ofende, ni ataca, ni usa represalias y deja a Dios el cuidado de la venganza', todo esto quiere decir, en suma, escuchándolo fríamente, y sin prejuicio, 'nosotros los débiles somos decididamente débiles; por consiguiente, haremos bien en no hacer todo aquello para lo cual no tengamos bastante fuerza'. Pero esta amarga comprobación [...], gracias a esta falsa moneda a este impotente engaño de sí mismo, ha tomado la exterioridad pomposa de la virtud, que sabe esperar".

Más dura resulta todavía la crítica de Freud, que se refiere no sólo al amor a los enemigos, sino incluso al amor al prójimo, sobre todo en el caso del precepto que ordena amarlo como a uno mismo. Estamos, según él, ante una modificación sustancial de la función amorosa, que razona así. Para la persona, el amor es algo muy precioso, que no puede malgastar insensatamente. Además, para poder amar a una persona, ésta debe merecerlo, porque, de lo contrario, resultará muy difícil, e incluso injusto, amarla. ¿Por qué tiene que amarse a una persona extraña?, se pregunta Freud. Pero aun en el caso de que hubiera que amarla por ser habitante de la tierra o criatura de este mundo, "como el insecto, el gusano y la culebra", sólo le correspondería una ínfima parte de amor, en ningún caso lo que la razón autoriza a guardar para uno mismo. Todavía le parece más inconcebible el precepto de amar al enemigo. Y como prueba de ello, cita uno

10. Estos y otros testimonios se encuentran en G. Theissen, Estudios de sociología del movimienro de Jesús, Salamanca, 1985, pp. 146-147; H. Küng, "Ecumene abrahámica entre judios, cristianos y musulmanes", en J. J. Tamayo, (ed.), Cristianismo y liberación. Homenaje a Casiano Floristán, Trotta, Madrid, 1996, pp. 43-58. 
de los "pensamientos y ocurrencias" del poeta alemán Heine, que - "por lo menos en broma", matiza - expresa aquellas verdades psicológicas más rigurosamenté condenadas.

Tengo la disposición más apacible que se pueda imaginar. Mis deseos son: una modesta choza, un techo de paja, pero buena carna, buena mesa, manteca y leche bien fresca, unas flores ante la puerta, y si el buen Dios quiere hacerme completamente feliz, me concederá la alegría de ver colgados de estos árboles a unos seis o siete de mis enemigos. Con el corazón enternecido, les perdonaré antes de su muerte todas las iniquidades que me hicieron sufrir en vida. Es cierto: se debe perdonar a los enemigos, pero no antes de su ejecución".

\section{Paz y justicia, inseparables}

En la tradición bíblica la paz es inseparable de la justicia y la violencia suele asociarse con la injusticia estructural. El término hebreo shalom posee una riqueza semántica que no se refleja adecuadamente en la eirene griega, en la pax latina o en los términos respectivos de nuestras lenguas. Shalom no significa la simple ausencia de guerras. Expresa, más bien, "una vivencia colectiva sazonada de bienestar, de serenidad, de salud corporal, de sosiego espiritual y de comprensión interhumana"'2 . Remite a un clima de plenitud, justicia, vida, verdad, que incide en el conjunto de las relaciones humanas: políticas, sociales, familiares, económicas, religiosas, etc. Posee, además, un componente ético, ya que exige un comportamiento humano integro, sin tacha. Esta riqueza semántica explica que shalom se empleara en la religión hebrea, y siga empleándose hoy entre los judíos, como saludo y bendición.

La verdadera paz nunca está disociada de la justicia. Sin la realización de ésta no es posible la paz. "La obra de la justicia será la paz - dice Isaías-, el fruto de la equidad, una seguridad perpetua" (Is 32, 17). Según la literatura profética, las estructuras sociales han de fundarse en la justicia (sedaga) y en el derecho (mispat). Los Salmos proponen la síntesis entre paz y justicia, amor y verdad (Sal 85, 11). Resumiendo las distintas tradiciones biblicas podemos decir, con el télogo argentino J. Míguez Bonino, que la paz es un proceso dinámico, mediante el cual se construye la justicia, en medio de las tensiones de la historia.

\section{La dialéctica paz-violencia en la historia del cristianismo}

La historia del cristianismo se mueve también en medio de la dialéctica paz y violencia o, si se prefiere, entre tolerancia e intolerancia: ambas no

11. La cita de Heine aparece en S. Freud, "El malestar en la cultura", Obras compleras III, Madrid, 1973, 3" ed., p. 3045, nota 1702. El texto resulta a todas luces, amén de cruel y despiadado, macabro.

12. A. Salas, "La paz, potencial realizador", Biblia y $\mathrm{Fe} 49$ (1991) 33. 
sólo se suceden en distintos momentos históricos, sino que coexisten simultáneamente.

Mientras la Iglesia fue perseguida, la libertad religiosa constituye el principio fundamental del cristianismo primitivo y la tolerancia, su práctica. Así lo atestiguan algunos de los textos de los té́logos de entonces. Escribe Tertuliano: "Es un derecho humano fundamental, un privilegio de la naturaleza, que todos los seres humanos procedan de acuerdo con sus propias convicciones. La religión de una persona ni perturba ni ayuda a otra. No está en la naturaleza de la religión que se imponga por la fuerza". Del mismo parecer es Lactancio, para quien "no hay nada tan voluntario como la religión; ésta desaparece y se hace nula si el sacrificio es ofrecido contra la propia voluntad".

En plena crisis arriana, san Atanasio defendió la libertad religiosa y se opuso al uso de la violencia contra los herejes: "Lo propio de una religión no es imponer, sino persuadir. El Señor no hizo violencia a nadie. Dejaba libres a todos y les decía: 'Si alguno quiere seguirme...'”. En el mismo sentido se definía san Hilario de Poitiers: "Si se emplease la violencia para establecer la fe, la doctrina episcopal se opondría a ello y dirfa: 'Dios es el Señor del universo y no tiene necesidad de un homenaje forzado"'.

Uno de los líderes más influyentes en el cambio de actitud de la Iglesia católica es Agustín de Hipona (354-439), que evoluciona del reconocimiento de la libertad de conciencia y religiosa a la defensa de la represión contra los herejes y cismáticos. Al comienzo de su ministerio episcopal se mostró contrario a utilizar penas severas contra los maniqueos, cuya doctrina habla seguido en su juventud. Creía que la persuasión, a través del debate intelectual, de la predicación y del diálogo con los heterodoxos sería suficiente para atraerlos a la "verdad de la fe". Así, escribía en el año 392 a los donatistas:

No es mi intención el obligar a los hombres a abrazar comunión alguna, sino manifestar la verdad a los que la buscan con ánimo apacible. Nuestros partidarios se abstendrán de aterraros con las potestades temporales. Aténganse los vuestros de aterramos con las partidas de los circunceliones (trabajadores del campo que servían de fuerza de choque a los donatistas). Atengámonos a la realidad, atengámonos a la razón, atengámonos a la autoridad de las divinas Escrituras.

Pero, al ver que la sola confrontación intelectual no daba los resultados esperados y que el donatismo representaba la ruptura de la unidad de la Iglesia, defendió el recurso a la fuerza, por parte de las autoridades civiles, para reducir a los herejes y cismáticos, y colocó en el mismo nivel de sanción los delitos civiles y los religiosos. Forzando el significado de los textos evangélicos, interpreta el "oblígalos a entrar" (compelle intrare) de la parábola del banquete real $(L c 14,21)$, en el sentido de que el Estado, además de la obligación de proteger a la Iglesia, debe utilizar 
todos los medios, incluso la violencia, para combatir la herejía y el cisma, y obligar a quienes han caído en una y otro a abrazar la verdad del cristianismo. Justifica la eliminatión de los cultos paganos para preservar la "unidad de la Iglesia".

El mismo Agustín, que al principio defendía la libertad del acto de fe, al afirmar que "el ser humano no puede creer más que si quiere", llega a mostrarse contrario a seguir la propia conciencia, salvo en el caso de que sea recta y considera que el monopolio de la verdad, en cuestiones éticas y religiosas, le corresponde al cristianismo. A su juicio, el error no tiene derechos, tesis que hacen suya los papas del siglo XIX, en su cruzada contra la modemidad.

A nadie se le oculta lo lejos que ha estado el cristianismo en su historia del ideal evangélico de la paz y de la práctica de la no violencia. Las iglesias han sido, al decir del téblogo alemán Herbert Vorgrimler, un "notable factor de discordia" y han conseguido imponerse con frecuencia por medio de la razón de la fuerza, más que con la fuerza de la razón persuasiva y testimonial. Matthias Metnner resume, en grandes trazos, la historia violenta del cristianismo asi:

La implicación de las iglesias en la violencia militar [...] se echa de ver en las cruzadas y en la reconquista española, en las feroces guerras de religión protestantes y católicas (desde aproximadamente el 1520 hasta terminar la guerra de los treinta años en 1648), en las brutales guerras de conquista de los conquistadores del nuevo mundo, anejas a una conciencia de envío y elección eclesiástica y misionera, en las bendiciones de la Iglesia sobre los combatientes de las guerras entre estados y naciones ("Dios con nosotros"), en el anticomunismo eclesiástico de la segunda guerra mundial ("contra el bolchevismo ateo"), que tuvo también una influencia decisiva después de 1945 sobre el pensamiento y la conducta de los cristianos ligados al sistema occidental [...], y en el desinterés y hasta hostilidad de las grandes iglesias frente a los movimientos confesionales, ecuménicos y extraeclesiales de nuestro siglo en favor de la paz ${ }^{13}$.

Sin embargo, también jalona la historia del cristianismo el otro polo de la dialéctica, la paz, a través de figuras relevantes y de acontecimientos significativos. Francisco de Asís fue defensor del diálogo islamo-cristiano y mantuvo un encuentro con el sultán Melek-el-Karnel para pacificar las conflictivas relaciones de los dos bandos contendientes. En plena época de legitimación religiosa de la guerra justa, dentro del franciscanismo, se desarrolló una teología de la paz y de la no violencia. Roger Bacon se mostraba contrario a la violencia contra los infieles y consideraba la argumentación racional y la filosoffa los únicos caminos para llevarlos a la verdad de la religión cristiana. Durante la edad media, destacó en la defensa del diálogo interreligioso el té́logo Juan de Segovia,

13. M. Mettner, "Paz", en P. Eicher, (ed.), Diccionario de conceptos teologicos, Barcelona, 1990, p. 185. 
defensor de la tesis conciliarista, en Basilea: preeminencia y superioridad del concilio sobre el papa. También Nicolás de Cusa, quien afirmó y reafimó en numerosos escritos el deseo de conseguir la paz, a través del diálogo y del respeto mutuo, y sin recurrir a métodos violentos. Resulta emblemática, a este respecto, su obra $L a$ paz de la fe, donde muestra cómo la mayorla de las guerras y violencias que se producen en el mundo, se deben a la religión y propone como hipótesis la existencia de una sola fe, basada en la creencia común en un solo Dios, dentro del reconocimiento y respeto a las diferencias en los ritos (una fides in rituum varietate). Con esta propuesta, se adelanta, en varios siglos, a los actuales principios de ecumenismo y tolerancia religiosa ${ }^{14}$. "A partir de Nicolás de Cusa - observa certeramente E. Gilson-, la inteligencia de la fe, más que la fe misma, tiende a convertirse en el principio de la paz y de la organización religiosa de la tierra"'s.

Es también la línea defendida por Pedro de Abelardo, en su libro Diálogo entre un filosofo, un judio y un cristiano ${ }^{16}$, y por Raimon Llull, en su obra $E l$ gentil y los tres sabios. En el Diálogo de Abelardo se encuentran tres hombres del medioevo, en un cruce de caminos: un filosofo, que confía en la ley natural, un judío, que defiende la alianza de Yahvé con sus antepasados y un cristiano, que cree en la palabra de Cristo, Verbo encamado. El filósofo defiende la superioridad de la ley natural sobre la ley de Moisés, y considera a ésta superflua, en lo concerniente a la consecución del bien espiritual. El judío defiende su propia identidad. El cristiano diseña una religión específica con pretensiones de universalidad como síntesis de las dos posiciones anteriores. Los tres tienen una meta común, aunque por caminos distintos: la búsqueda de Dios como bien supremo del ser humano, bajo la guía de la razón y con un juez que tiene que dictar el veredicto. El principal desafío que tiene delante el Diálogo es la convivencia, la unidad en la diversidad, la razón que no renuncia a la verdad.

Ésa es la senda seguida por Raimon Llull, en El gentil y los tres sabios, que imagina un diálogo en tomo a la fe entre un pagano y tres sabios, representantes de las tres religiones monoteístas, judaísmo, cristianismo e islam. Cada uno va proponiendo al gentil el contenido de su religion. Cuando todos han terminado su exposición, el gentil dirige una alabanza a Dios. Ninguno de los tres sabios osó preguntarle cuál de las religiones había abrazado, ni a qué Dios se había dirigido en la oración de alabanza. Antes de despedirse y de partir cada uno para su lugar de residencia, los tres sabios se pidieron perdón y acordaron seguir dialogando.

14. Cfr. N. Cusa, La paz de la fe y Carra a Juan de Segovia. Estudio preliminar, traducción y notas de Víctor Sanz Santacruz, Madrid, 1999.

15. Citado por Victor Sanz Santacruz, p. XVI.

16. Cfr. Abelardo, Diblogo entre un filbsofo, un judio y un cristiano, edición bilingile, estudio preliminar, traducción y notas de Silvia Magnavacca, Buenos Aires, 2003. 
Otro ejemplo luminoso de trabajo por la paz fue Bartolomé de Las Casas, quien, en plena conquista de Amerindia, de eliminación de las creencias religiosas indfgenas y de imposición violenta de la fe cristiana a la población autóctona, llevó a cabo una evangelización liberadora, a través de la persuasión, y no de la violencia, defendió la dignidad de los indios frente a los conquistadores y encomenderos, muchos de los cuales no los consideraban personas, e intervino decisivamente en la elaboración de las leyes que reconocían los derechos humanos de los indígenas. Su filosofía de la tolerancia, que Francisco Fernández Buey llama variante latina de la filosofía moral y política de la alteridad, se adelanta a la filosofía moral y política de los ilustrados de siglos posteriores y es mucho más tolerante con las culturas no europeas que aquéllos ${ }^{17}$. Hoy constituye un referente irrenunciable, en el debate sobre la interculturalidad, de la cual Las Casas bien puede ser considerado un precursor ${ }^{18}$.

En la misma época destacan, por su talante pacificador y tolerante, influyentes intelectuales, entre los que cabe citar a Moro y Erasmo. Tomás Moro fue traductor de la vida del humanista italiano Juan Pico de la Mirandilla, cuyo ejemplo quiere seguir. Escribió Utopía, la primera obra que inicia un nuevo género literario, en el renacimiento: el utópico, seguido posteriormente por Bacon, Campanella y otros. Fue un crítico severo, primero de Enrique VII y después de su sucesor, Enrique VIII, quien mandó ejecutarlo, en 1535. Erasmo de Rotterdam defendió un cristianismo humanista, se opuso a toda forma de absolutismo, defendio y practicó la tolerancia como respeto' ${ }^{19}$.

La obra más emblemática de la tolerancia y del diálogo interreligioso de la modernidad europea, en plena ilustración, es Nathan der Weise (Natán el Sabio), de Lessing, ejemplo de diálogo interreligioso entre un judio, un musulmán (el sultán saladito) y un cristiano. Hans Küng define esta pieza teatral como "un drama de reconciliación utópica", que propone la utopía político-religiosa de un futuro mejor para la humanidad, representada simbolicamente en la escena final, a través de la fiesta del abrazo de los creyentes de las tres religiones monoteístas ${ }^{20}$.

17. F. Fernández Buey, La gran perturbación. Discurso del indio metropolitano, Barcelona, 1995.

18. J. J. Tamayo, "Las Casas: de la identidad del indio a la interculturalidad en el Tercer Milenio", en V Centenario del primer viaje a América de Barrolomé de Las Casas (I502-2002), Junta de Andalucla, Consejerla de la Presidencia y Consejería de Cultura, Sevilla, 2003, pp. 133-147.

19. He desarrollado más ampliamente este tema en "Las religiones en tiempos de globalización", en J. J. Tamayo, (dir.), Diez palabras clave sobre globalización, Estella (Navarra), 2002, pp. 357-396, para el tema, pp. 365-373.

20. Cfr. G. E. Lessing, Natán el Sabio, traducción e introducción de Agustín Andreu, Madrid, 1985; Jiménez Lozano, Martínez, R. Mate, y J. Mayorga, Religión y Tolerancia. En torno a Natán el Sabio de Lessing, Barcelona, 2003; H. Küng, El cristianismo. Esencia e historia, Madrid, 1997. 
La dialéctica paz-violencia sigue hoy, y con más intensidad, si cabe, que en el pasado. Hay un cristianismo que apela a Dios para legitimar un discurso y unas prácticas políticas belicistas, todo ello revestido de "teología de la seguridad", y un cristianismo que apela a las tradiciones pacificadoras, que se encuentran en los textos fundantes y en los movimientos pacifistas, que jalona la historia del cristianismo. El primer cristianismo está representado ejemplarmente por los nuevos cruzados del siglo XXI, que declaran la guerra total contra el "eje del mal", a partir de la "teología de la seguridad" y de la "teología neoliberal", reveladas a Hayek, en el Monte Peregrino, lugar de encuentro de los políticos y economistas neoliberales, a Bush, en el Pentágono, y a Ariel Sharon, en el monte Sinaí.

Es la imagen de Dios que Martin Buber describió en estos términos: "Dios es la palabra más vilipendiada de todas las palabras humanas. Ninguna ha sido tan mancillada, tan mutilada [...] Las generaciones humanas han hecho rodar sobre esta palabra el peso de su vida angustiada, y la han oprimido contra el suelo. Yace en el polvo y sostiene el peso de todas ellas. Las generaciones humanas, con sus partidismos religiosos, han desgarrado esta palabra. Han matado y se han dejado matar por ella. Esta palabra lleva sus huellas dactilares y su sangre [...] Los hombres dibujan un monigote y escriben debajo la palabra 'Dios'. Se asesinan unos a otros, y dicen: 'lo hacemos en nombre de Dios' [...] Debemos respetar a los que prohíben esta palabra, porque se rebelan contra la injusticia y los excesos que con tanta facilidad se cometen con una supuesta autorización de 'Dios' ¿Qué bien se comprende que muchos propongan callar, durante algún tiempo, acerca de las 'últimas cosas' para redimir esas palabras de las que tanto se ha abusado".

Hay, sin embargo, otro discurso que condena las últimas guerras e invasiones del imperio: la del golfo, la de Afganistán y la de Irak. Hay otras prácticas, las de los movimientos cristianos a favor del desarme y de la paz, que se han sumado a las manifestaciones contra la guerra y el capital, y a favor del diálogo y de la no violencia como únicos métodos eficaces para la resolución de los conflictos, a escala nacional e internacional. En este caso, la apelación no ha sido al "Dios de los ejércitos", sino al Dios de la paz, de la reconciliación, de la compasión y de la vida. El mandamiento al cual responden es "¡No matarás!", que se convierte en imperativo categórico de obligado cumplimiento, en todo tiempo y lugar. El clamor que resuena por doquier es " $i$ No a la guerra en nombre de Dios!".

\section{Paz en el cristianismo, paz en las religiones, paz en el mundo}

Concluyo ya. Y lo hago con una reflexión sobre la aportación de las religiones a la paz, en un momento en que se defiende el choque de civilizaciones. Históricamente, las religiones han atizado y siguen atizando muchos conflictos. Y el cristianismo también. Pero pueden jugar un papel decisivo en la construc- 
ción de la paz. Para ello es necesario un cambio de paradigma en la relación entre ellas: pasar del anaterna al diálogo, del choque de civilizaciones a la interculturalidad. Bajo la inspiración de Hans Küng, propongo los siguientes principios ${ }^{21}$ :

- No habrá paz entre las naciones sin paz entre las religiones. Más de tres cuartas partes de la población mundial están vinculadas a alguna religión. Si estas personas activan sus tradiciones religiosas pacificadoras resultará más fácil la solución de los conflictos de forma pacífica.

- No habrá paz entre las religiones sin diálogo entre ellas. Un diálogo que debe caracterizarse por la simetría, la correlacionalidad, la corresponsabilidad y el respeto al pluralismo religioso, nunca por el proselitismo.

- No habrá diálogo interreligioso si las religiones no se conocen entre sí. El desconocimiento constituye el caldo de cultivo para las descalificaciones mutuas. El conocimiento riguroso y en profundidad de las religiones, a través de las distintas disciplinas que se ocupan de su estudio, facilitan la comprensión entre ellas.

- No habrá diálogo entre las religiones sin una ética global. Las religiones pueden colaborar en la construcción de dicha ética, asumiendo una serie de tareas, que ya indicamos más arriba: trabajo por la no violencia y respeto de la vida; defensa de la naturaleza, sometida a explotación por el actual modelo de desarrollo científico técnico; opción por los sectores, pueblos y continentes excluidos; apuesta por una cultura de la solidaridad y por un mundo donde quepan todos los mundos; trabajo por un orden económico justo; promoción de una cultura de la igualdad y la colaboración entre hombres y mujeres, frente a la cultura patriarcal hoy imperante, en todas las sociedades.

- No habrá ética universal sin diálogo intercultural, ya que dicha ética debe respetar las peculiaridades de cada cultura, siempre dentro del reconocimiento y del más escrupuloso cumplimiento de los derechos humanos.

21. Cfr. H. Küng, Proyecto de una ética mundial, Madrid, 1990; J. J. Tamayo (dir.), Diez palabras clave sobre paz y violencia en las religiones, Estella, 2004. He hecho un desarrollo más fundamentado de estas propuesta en mi libro, Fundamentalismos y diálogo entre religiones, Madrid, 2004. 